\title{
KNOWLEDGE TRANSFER \\ IN A KNOWLEDGE-BASED ECONOMY
}

\author{
Hana Urbancová, Lucie Vnoučková, Šárka Laboutková
}

\section{Introduction}

The OECD member states passed through three fundamental development stages during the last century: from an industrial society in the first half of the $20^{\text {th }}$ century to a post-industrial society and on to the developmental stage of the so-called new economy, which can be considered to involve the relatively long historical period of economic growth in the 1990s. The effects of the knowledge economy manifested themselves positively in the last decade of the $20^{\text {th }}$ century and the significance of human capital as an essential factor for long-term economic growth was unequivocally confirmed (Kruss et al., 2015). The knowledge economy corresponds both to the theories of endogenic growth and especially to the alternative directions for contemporary socio-economic approaches to the theory of growth. Theories incorporating the knowledge economy place an emphasis on the importance of knowledge, information and technical skills, i.e. know-how, as the basic resource for the development of the economy (Lilles \& Rõigas, 2015). This is the precondition for a so-called resource approach to the creation of a competitive advantage where know-how is considered to be the most significant of the production factors (Kislingerová, 2011). Talented young people, high quality institutions within the framework of the entire system, the appropriate funding of organizations, a strong infrastructure, including the e-Science infrastructure and the existence of scientific leaders are considered to be important components in the knowledge economy, while the key abilities are considered to be an appetite for risk and the ability to utilize international cooperation with the aim of strengthening the original initiative (Chidambaran, 2014).

It is possible to view the knowledge economy as a collective term for the current distinctly positive supply shock, at the core of which lies the rapid development of information and communication technology (Kruss et al., 2015; Nečadová, Soukup, \& Breňová, 2007). Its wide use brings with it ever increasing requirements when searching for and processing information and an emphasis on knowledge and its application in practice (Kloudová, 2012). The key source of success is no longer information as such, but the right knowledge which is associated with a specific bearer - employee who must constantly develop this in a currently highly competitive environment.

The active use of knowledge is therefore unquestionably a competitive tool for individual organizations. An organization is part of the system from which it draws its resources. The conditions set up in it and the way they are influenced by the state have a substantial influence on the options of using knowledge as a communication tool in a given branch and in a given organization. Macroeconomic, but also microeconomic, policies therefore have a substantial impact on innovative development.

The correctly adjusted knowledge economy must endeavor to achieve a cutting edge level of basic research and applied research. According to Chidambaram (2014), it is currently necessary to emphasize not only the strengthening of academic and practical interaction, but also excellent results in the area of research and development based on innovation. However, this must also be supported with first rate knowledge, skills and experience (Arvanitis et al., 2015; Levy, 2011). The results of the Hansen, Winther and Hansen (2014) research have showed that human capital has a positive impact on economic growth in the branch in which the organization is located. It is the private sector which designates the innovative capacity of the economy to a critical extent. Suitable economic policies applied for the purpose of the internalization 
of existing externalities and the setting of suitable framework conditions for the creation of innovation may support important innovation for this sector, the individual branches and the organization itself (Hobza, 2009). The research undertaken by Chidambaram (2014), Levy (2011) or Hansen, Winther and Hansen (2014) has looked into the standing of organizations in the knowledge economy, primarily in the tertiary sector. However, knowledge stands at the forefront of the interests of all the types of organizations in all the branches. Its effective use leads to the prosperity of the organization, the branch and the entire economy and this will unquestionably continue to be the case for a long time to come (Tosici, 2014). The knowledge economy currently presupposes that each organization manages its knowledge and in doing so intentionally endeavors to achieve a long-term competitive advantage.

The goal of this article is to identify and evaluate the conditions for the use of the resource approach focused on the management of knowledge in the current knowledge economy across all economic branches. The article's secondary goals are:

- to provide a summary of the viewpoints (standpoints) of individual authors who have concerned themselves with the area of the knowledge economy, knowledge management, competitive advantage and the influence of the state on the creation of market conditions,

- to present the results of primary research into the area of knowledge transfer within organizations in the Czech Republic,

- to propose measures in the area of improving the effectiveness of the knowledge management process in organizations.

The structure of the paper is as follows: the theoretical background of the work is presented first; this is followed by the paper's methodology which describes the paper's preparation. Furthermore, the results have been evaluated and we have proposed recommendations for the use of knowledge transfer in knowledgebased organizations. Finally, the paper also presents the theoretical and practical benefits and limitations which apply to it.

\section{Theoretical Background}

According to Matula (2011), the concept of the knowledge economy is becoming a daily part of the routine life of all the citizens of advanced economies throughout the world. For this to be so, however, it is necessary for each individual organization in each member state to concern itself with effective knowledge transfer, to support the personal development of their employees and in doing so to increase the organization's knowledge base. Based on Levy (2011), it is possible to support a knowledge approach to the creation of the competitive advantage using effective knowledge transfer and thus to create a relatively permanent competitive advantage for the organization and the economy as a whole. An economy based on knowledge should be the current and future goal for everybody. The first step in support of the knowledge economy is a focus on effective knowledge transfer within an individual organization and how this knowledge transfer system is set up inside the organization.

Learning is individually driven and once individuals have learned some skills the next question is how the organization should incorporate its procedures and assets. In other words, individual learning needs to be transformed into organizational learning (Kumaraswamy \& Chitale, 2012). Organizational learning takes place when the organization concerned addresses a particular problem which the organization needs to solve. As such, the problems are confronted during the learning of lessons and the assimilation of competences which represent the collective learning of the present, past and future employees. Organizational learning is described as the way organizations build, supplement and organize their knowledge and routines around their business activities and business cultures, as well as the way they adopt and develop organizational efficiency by improving the use of the broad skills of their workforces (Fiol \& Lyles, 1985).

Organizational learning theories provide rich perspectives on the processes that generate and change organizational knowledge. Learning provides the skills, insights and competence to perform well at work. It enables people to adapt and grow in their workplaces and to become better problem solvers, more creative and innovative thinkers and more confident and proficient workers. Organizational learning can be considered to constitute the systematic behavior required to acquire the capacities for dealing with the needs and challenges of organizations in competitive environments. 
The essential key elements of knowledge sharing are a climate of trust and openness in the working environment where continuous learning and experimentation are well supported (Kumaraswamy \& Chitale, 2012). The overall benefits of learning in an organization focused on its employees fall into two main categories; career advancement and psychosocial support (Beech \& Brockbank, 1999; Gannon \& Maher, 2012). These professional and personal advantages are evident via more promotions, higher salaries, more job satisfaction and reduced levels of worker turnover (Allen et al., 2004). Learning and education also have an impact on social capital and social networks (Bozionelos, 2006; Hezlett \& Gibson, 2007; Singh et al., 2009). The recognition of social capital as offering valuable insights into organizational learning is built upon the premise that access to intellectual and economic capital is now more available than ever before (Hezlett \& Gibson, 2007). Therefore the social capital perspective of employees and their organizations can be seen in the understanding, developing and leveraging of relations with others which can further develop their careers and competitive success (Singh et al., 2009).

Employees who are being educated and developed are usually highly interested in working towards organizational goals and following the organizational strategy; they are communicative, cooperative, proactive, respectful, customer-friendly, willing and able to constantly learn (Li et al., 2009; Vnoučková, 2013). As Mazouch and Fischer (2011) and Gururajan and Fink (2010) have stated, measuring the level of education in organizations is necessary for predicting future developments.

De Luis Carnicer et al. (2004), Pearce and Randel (2004), Branham (2009), Vnoučková (2013) and Zeman (2009) state that it is necessary to cater for employees' needs in terms of their education and development; otherwise, there is a possibility that the organization in question will lose those employees. The necessity of retaining educated, trained and skilled employees has also been noted by the European Union. The key indicators of the Europe 2020 Strategy focuses primarily on the sustainability of employees and employment. Focusing on people and knowledge is the priority of all of Europe. The main priorities of the knowledge society up to 2020 are above all productivity, education and employment and their impact on the development of Europe.

Covey (2011) and Peters (2011) state that the use of sustainable values which lead to sustainable development is crucial for the future development of employees; these values specifically include: cooperation, ethics, integrity (relationships), quality and values for the next generation. The authors argue that the main decisions which have proved to be right and persistent (and the authors have supported this with many examples) do not often result from economic, financial or other analyses (which according to Peters (2011) have caused the current crisis); on the contrary, they are based on the employees' abilities, their character, relationships and common values (cooperation, sacrifice, adherence to and orientation towards goals, results and needs and a focus on the customer as a person and a citizen).

Based on Svatoš's research (2005), it can be said that it is important to invest in the constant development of employees, because the growth in investments in human capital positively influences the growth in work productivity. This is based on the fact that the higher education (growth in the qualification level) of the employees is a significant factor (source) of economic growth on the one hand, but it also has a supportive effect on the efficiency of other crucial factors affecting this growth, i.e. on the use of the effects of technological progress and production management and organization or the effects of the scope and specialization of production. All of these factors are essential to support the economy as a whole. Bureš \& Hájek (2007) added that it is necessary to realize that the creation and realization of each knowledge economy (i.e. innovations and the application thereof) require an active approach, both at the level of the individual organizations and at the level of the individuals themselves. Without the personal development of individuals, it is not possible to achieve positive results at either the level of the organization or the entire economy, which has also been confirmed by the research undertaken by Arvanitis et al. (2015).

With regard to the aforementioned information, this paper focuses on the current situation with regard to knowledge transfer in organizations in the Czech Republic which has been evaluated on the basis of long-term research undertaken within organizations in all sectors of the economy. The acquired data and 
the evaluation thereof has been compared with the results of similar research realized abroad.

\section{Data and Methods}

Analysis and the comparative method have been used to analyze the theoretical basis and terms. The analytical section of the paper has been based on deductions and the synthesis of the acquired knowledge. The recommendations are based on quantitative research realized using questionnaire data collection techniques across the economic branches (CZ-NACE). The research is descriptive and empirical by nature, because the primary data has been collected using the survey method, including fact-finding techniques such as questionnaires and interviews. The data for the evaluation of the current level of education and learning in Czech organizations has been collected in a primary quantitative survey by means of a questionnaire. Only one respondent per business was contacted. The questionnaire was completed on behalf of the organization by a respondent who held a managerial position (had at least one direct subordinate). The data collection respected the ethical aspects of research (Personal Data Protection Act no. $101 / 2000$ Coll.).

\subsection{Research Sample}

Randomly selected organizations were contacted by e-mail, the electronic questionnaire was automatically recorded and the respondents' answers were precategorized (the CAWI method). The selected sample was chosen from the database of Czech organizations based on distribution of organizations in economy presented by Czech Statistical Office; therefore the group was representative. The results were generalized on selected sample. In order to ensure the findings are evaluable and generalizable with respect to the sample group the selection criteria for the survey have been set in a way to roughly reflect the proportional representation of organizations according to the sector of economy (15\% primarily, $15 \%$ secondary, $70 \%$ tertiary) and organizations' size (65\% small, $20 \%$ middle, $15 \%$ large). In order to ensure the representativeness of the group of respondents the questionnaire survey was completed by a person who held a managerial position, mostly by the company manager or the human resources department manager.
The questionnaire consisted of four parts which included 15 questions in total. The first section focused on knowledge transfer in organizations (11 questions) and the last section focused on classification questions. Most of the questions were closed-ended. By 2014, a total of 278 organizations had participated in the questionnaire survey:

- by economic sector: $3.6 \%$ from the primary sector, $16.9 \%$ from the secondary sector and $79.5 \%$ from the tertiary sector

- by size of business according to the number of employees: $71.6 \%$ small, $14.4 \%$ mediumsized and $14.0 \%$ large organizations.

The questionnaire focused on the areas of organizational support for knowledge, education and learning, employees' attitudes toward knowledge, education and learning and the targets for education and learning and its outcomes - innovations, promotions, organizational growth.

\subsection{Data Processing}

The first stage of processing the questionnaire results focused on the preparation of a data matrix. The data was described and then it was coded and sorted according to the type of variables (qualitative, quantitative). During this phase, the data was also cleaned and its quality was checked in order to uncover any extreme (eccentric) or deviating observations which could significantly influence the results of some analyses. An integral part of this stage included an analysis of any missing values which was meant to identify and replace any such missing values. The last part of the data matrix involved the transformation of the variables which was necessary for several reasons. When processing a multidimensional data file, the reason for this is usually the requirement for the fulfilment of the conditions of a certain statistical method.

The respondents' answers were categorized according to the identification questions which formed the first part of the questionnaire. In the survey, the measurement was based on closed questions with one or more possible answer(s) which had been selected on the basis of a study of the literature, documents and other related surveys.

A semantic differential which permitted the identification of nuances in the respondents' attitudes throughout the questionnaire was also applied. The respondents' reactions to 
target statements and their attitudes to the given matter were restricted by offering a set of several statements. The extremes of the sevenpoint scale represented bipolar concepts of the evaluation dimension. Using a scale of 1 to 7 , respondents expressed their inclination towards one of the pre-set extreme statements or, if it was not possible to favor either of the sides, selected a median, neutral value (the median value was characterized by the number 4 ). The scale permitted not only the specification of the respondents' attitudes, but also their intensity.

The second stage focused on the actual processing of the results. The research analysis of the data realized in this stage focused on investigating the important properties and the typical features of the statistical file. The statistical evaluation of the data was undertaken on the basis of:

- a one-dimensional analysis based on the frequency distribution, the calculation of descriptors, point and interval estimates and the testing of hypotheses about the frequency of the categories of individual variable values.

- a multidimensional analysis based on an investigation into the dependence of two or more variables. The goal of the comprehensive analysis of several variables was to uncover any multidimensional latent data structures and to find an interpretation for these structures. The retrieval of the information in the data file was realized using classic Pearson hypothesis testing, while the classification of the higher levels was achieved using a factor analysis. Pearson's Chi-square test and Cramer's $\checkmark$ were applied. If the $p$-value calculated by means of the $\mathrm{x} 2$ test (Pearson ChiSquare) was lower than the selected level of significance $\alpha=0.05$, the null hypothesis was rejected. Factor analysis performed a verification role in this paper. The KaiserGuttman rule was also applied to select the group of significant factors; based on the recommendations of Anderson (2009), only determinants with an absolute value of more than 0.3 were selected as being significant for factor development.

The processing of the results of the research was undertaken using IBM SPSS Statistics, version 22. This software is a comprehensive tool for the resolution of statistical tasks and analytical problems. The SPSS software enables the transfer of results to all professional software packets and this also secures the subsequent transferability of the data.

\subsection{Tested Hypotheses}

A correlation analysis was used to review the survey output based on the stated results. The following hypotheses were postulated in order to review the results:

The main hypothesis in this paper is $\mathrm{HO}$ : The organizations do not support knowledge transfer.

The tested work hypotheses are stated below.

$\mathrm{H} 1$ : There is no dependence between the supportive process in the organization and the support for the employees with regard to their knowledge development initiatives (training, education and learning).

$\mathrm{H} 2$ : There is no dependence between the availability of mentors in the organization and the support for the employees with regard to their knowledge development initiatives.

$\mathrm{H} 3$ : There is no dependence between the availability of feedback and the support for the employees with regard to their knowledge development initiatives.

$\mathrm{H} 4$ : There is no dependence between inspiring leaders in the organization and the support for the employees with regard to their knowledge development initiatives.

$\mathrm{H} 5$ : There is no dependence between the rewards for learning in the organization and the support for the employees with regard to their knowledge development initiatives.

$\mathrm{H} 6$ : There is no dependence between the requirement for learning in the organization and the support for the employees with regard to their knowledge development initiatives.

$\mathrm{H} 7$ : There is no dependence between the time invested in learning in the organization and the support for the employees with regard to their knowledge development initiatives.

$\mathrm{H} 8$ : There is no dependence between the clear learning goals in the organization and the support for the employees with regard to their knowledge development initiatives.

H9: There is no dependence between the work-life balance in the organization and the support for the employees with regard to their knowledge development initiatives.

$\mathrm{H} 10$ : There is no dependence between the succession in the organization and the support for the employees with regard to their knowledge development initiatives. 
$\mathrm{H} 11$ : There is no dependence between the innovations in the organization and the support for the employees with regard to their knowledge development initiatives.

\section{Research Results}

The objective of this chapter is to evaluate the results obtained from the primary surveys. The results of the quantitative research have been statistically evaluated and recommendations have been formulated upon this basis.

\subsection{Knowledge Transfer in Czech Organizations}

On the basis of long-term research into education and knowledge sharing in organizations, it can be summarized that the absolute majority of organizations are aware of the fact that the permanent development of their employees is currently an essential part of the organization's operations. Thanks to the constant increase in knowledge and the deepening thereof, it is possible to acquire key knowledge based on experience which secures a relatively long-term competitive advantage for the organization. Unlike general knowledge which wears out and loses its value over time, key knowledge is held by just a small number of individuals and the wear and tear of this knowledge actually increases its value.

The results which were acquired from the organizations whose representatives took part in the research can be summarized by saying that $82.37 \%$ of organizations place an emphasis on the education of employees and regularly invest in the development of their employees' knowledge. In total, $14.29 \%$ of organizations in the Czech Republic do not put any money into training, $64.29 \%$ of them invest $1-5 \%$ of the amount of their annual staff salaries, $14.29 \%$ of organizations invest $6-10 \%$ of the amount of their annual salaries and $7.13 \%$ invest from $11-20 \%$. None of the observed organizations invested more than $20 \%$ of the amount of their annual salaries.

Most organizations realize education and knowledge development as a planned activity which is planned for a certain period with tasks which must be undertaken in the period between the individual courses $(21.58 \%)$. A total of $7.19 \%$ of organizations realize permanent education with an internal or external teacher active directly in the workplace, $5.76 \%$ or organizations have education focused purely on the compulsory area of education (the laws, occupational safety and so on) and $21.22 \%$ of organizations realize the education and development of their employees unsystematically, once the need has been identified. This involves small companies (up to 20 employees) which do not have sufficient funds and at the same time do not consider the development of their employees to be critical. On the other hand, $26.62 \%$ of organizations realize planned education, during which a series of educational activities is planned for a certain period.

In the currently ongoing research $(n=387)$, the situation is even more positive, because $299(77.26 \%)$ organizations provide education for their employees. This involves a planned activity which is systematically realizable and evaluated by the management. This situation usually applies in medium-sized and large organizations which have created an HR Department and where the area of the education and development of the organization's employees is looked after by the organization's specialist employees who assist the individual employees.

Given the importance of preserving information within the organization and the continual support for the organization's knowledge base, it is necessary to preserve the knowledge in a suitable manner and to do so using technical means, etc. In total, $20.50 \%$ of the organizations $(n=278)$ stated that they were trying to maintain everybody's knowledge with regard to the competitive advantage they had achieved thanks to the knowledge, while $55.76 \%$ of organizations only stored key knowledge which provided the organization with a unique competitive advantage. These organizations most frequently make use of knowledge databases and information systems for the collection and sharing of knowledge in the organization. A total of $23.76 \%$ of organizations have not yet begun to store any such information as they have not yet had to resolve a crisis situation during a change of personnel (for example, the departure of a key employee to the competition).

The conclusiveness of the factors affecting employee willingness to knowledge sharing is shown in Tab. 1. A correlation analysis at the level of significance of 0.01 indicates direct, strong dependence. 
Tab. 1: Relations between factors and employee willingness to knowledge sharing

\begin{tabular}{l|c}
\multicolumn{1}{c|}{$\begin{array}{c}\text { Relation between factors and willingness } \\
\text { to knowledge sharing }\end{array}$} & Pearson's coefficient \\
\hline Culture & 0.99072 \\
\hline Communication & 0.88209 \\
\hline Relationships & 0.92022 \\
\hline
\end{tabular}

Source: data processed by the authors

Organisational causes of employees' decision to share knowledge are interwoven with personal and informal aspects, as shown in Tab. 1. Positive relationships and their experiencing create favourable predispositions for the strengthening of motivation of employees to work well, perform better and share knowledge. Personal satisfaction is the main precondition of work satisfaction. Internally balanced employees perform better even despite worse conditions.

The organization must inform its individual employees with regard to the procedure which supports the creation of the organization's competitive advantage. If this is a knowledge approach, the organization should acquaint its employees with a long-term systematic education and development plan, incorporate them in innovative teams, support them on internships abroad and enable them to participate at conferences etc., i.e. support research and development. The results have unequivocally shown that $44.24 \%$ of employees who identify with the organization's culture and have been acquainted with the organization's long-term goals are willing to share their knowledge with colleagues. They help their colleagues at work, because they believe in the positive effect achieved by spreading knowledge through the organization and they are aware of the impacts of the organization's higher knowledge base in relation to the competition. A better financial situation in the company based on the successes of individuals and teams brings a positive effect to all the participating parties (i.e. to the workers, the organization and the national economy). It can be summarized that support of cooperation forms between organizations, good and friendly communication between current employees and support of friendly relationships are the main areas which affect knowledge development in organizations nowadays.

\subsection{The Parameters Pertaining to Knowledge Development in an Organization}

According to the results of the quantitative research focused on education in Czech organizations, $66.5 \%$ of the surveyed organizations make use of some type of education or training at work. However, one third of Czech organizations still do not educate their employees and do not work with knowledge development and management in any way.

About the same percentage of organizations (73\%) use some version of MBO (Management by Objectives). In consultation with their manager or supervisor, the employees set a specific goal which they want to achieve within a given time period and which is relevant to their area of learning and growth. Such a result gives the impression that organizational learning and development is a long-term process; $63 \%$ of the evaluated employees said they perceived their education and learning as a long-term process. Short-term goals and training or courses with a single purpose are used in $23 \%$ of organizations. One third of the organizations still do not set any specific goals and targets for education and knowledge development.

Similar results were obtained with regard to specific knowledge/skill training in organizations. Almost $66 \%$ of employees stated that their education and learning in the organization was focused on specific skills related to their work. Moreover, the surveyed organizations stated that they offered job positions with the option of growth $(89 \%)$. But this option depended mainly on the employees themselves. $70 \%$ of organizations require their employees to invest additional time (to study at home in their free time). Therefore, employees are expected to be proactive and to work on their own development, otherwise they would have no possibility for future growth and development. 
Only $37 \%$ of the organizations provide motivation for education and learning with long-term intangible rewards. As mentioned above, the main activity and initiative lies with the employees. Simultaneously, $44 \%$ of the organizations do not support or encourage their employees to undergo any education at all. Almost the same results were obtained when focusing on tangible rewards (money and benefits). Just $33 \%$ of organizations support education and learning in the aforementioned way; on the other hand, $56.5 \%$ of organizations do not reward their employees' active participation in education at all.
The hypotheses stated in Data and Methods were then tested further. All the hypotheses had two variables. Spearmen's rank correlation coefficient ( $r$ ) was thought to be the most appropriate way to test the hypotheses as these variables were measured on the ordinal scale. The parameters were tested at 5 per cent significance (Tab. 2).

Table 2 clearly shows that all the parameters correlate with the support for the employees in their initiative pertaining to knowledge development. It is, therefore, possible to evaluate the hypotheses.

\section{Tab. 2: The parameters pertaining to knowledge development in the organization}

\begin{tabular}{|c|c|c|c|c|}
\hline & & $\begin{array}{l}\text { Spearmen's } \\
\text { rank } \\
\text { correlation }\end{array}$ & Acceptance & $\begin{array}{c}\text { Power } \\
\text { dependence }\end{array}$ \\
\hline $\mathrm{H} 1$ & $\begin{array}{l}\text { the support process in the organization - the } \\
\text { employees' initiatives pertaining to knowledge } \\
\text { development }\end{array}$ & 0.48 & Yes & Moderate \\
\hline $\mathrm{H} 2$ & $\begin{array}{l}\text { mentors in the organization - the employees' } \\
\text { initiatives pertaining to knowledge development }\end{array}$ & 0.29 & Yes & Weak \\
\hline H3 & $\begin{array}{l}\text { feedback in the organization - the employees' } \\
\text { initiatives pertaining to knowledge development }\end{array}$ & 0.53 & Yes & Strong \\
\hline $\mathrm{H} 4$ & $\begin{array}{l}\text { inspiring leaders - the employees' initiatives } \\
\text { pertaining to knowledge development }\end{array}$ & 0.52 & Yes & Strong \\
\hline H5 & $\begin{array}{l}\text { rewards for learning in the organization - the } \\
\text { employees' initiatives pertaining to knowledge } \\
\text { development }\end{array}$ & 0.47 & Yes & Moderate \\
\hline $\mathrm{H} 6$ & $\begin{array}{l}\text { required learning in the organization - the } \\
\text { employees' initiatives pertaining to knowledge } \\
\text { development }\end{array}$ & 0.43 & Yes & Moderate \\
\hline $\mathrm{H} 7$ & $\begin{array}{l}\text { time invested in learning in the organization } \\
\text { - the employees' initiatives pertaining to } \\
\text { knowledge development }\end{array}$ & 0.53 & Yes & Strong \\
\hline $\mathrm{H} 8$ & $\begin{array}{l}\text { clear learning goals in the organization - the } \\
\text { employees' initiatives pertaining to knowledge } \\
\text { development }\end{array}$ & 0.34 & Yes & Moderate \\
\hline $\mathrm{H} 9$ & $\begin{array}{l}\text { work-life balance in the organization - the } \\
\text { employees' initiatives pertaining to knowledge } \\
\text { development }\end{array}$ & 0.21 & Yes & Weak \\
\hline $\mathrm{H} 10$ & $\begin{array}{l}\text { advancement in the organization - the } \\
\text { employees' initiatives pertaining to knowledge } \\
\text { development }\end{array}$ & 0.53 & Yes & Strong \\
\hline H11 & $\begin{array}{l}\text { innovations in the organization - the employees' } \\
\text { initiatives pertaining to knowledge development }\end{array}$ & 0.44 & Yes & Moderate \\
\hline
\end{tabular}


The first parameter of $\mathrm{H} 1$ the support process in organization was positively correlated at a 5 per cent level of significance with the support of the employees in their initiative pertaining to knowledge development.

The same situation occurred in the testing of the rest of the hypotheses. The variables were associated, because their parameters were positively correlated at a 5 per cent significance. Hypotheses $\mathrm{H} 2-\mathrm{H} 11$ have been rejected. Only hypotheses $\mathrm{H} 2$ and $\mathrm{H} 9$ have weak correlations. In the case of $\mathrm{H} 2$, this is due to the fact that mentors are not commonly used in Czech organizations (only one third of the organizations work with mentors). In the case of $\mathrm{H} 9$, it is possible to state that the fact that employees are also forced to study and develop themselves in their free time affects and does not correlate with their work-life balance. In summary, all of the tested variables are associated with knowledge development in Czech organizations.

\section{Discussion}

Based on the presented results of analysis it can be summarized that there is a relationship between knowledge support and knowledge development in organizations; organizations does support knowledge transfer $(\mathrm{H} 0)$ but there are some promising areas of knowledge development in the organizations. The strongest and most significant statistical areas which affect knowledge development in organizations are based on cooperation and communication, hence the organizational culture, as mentioned by Kumaraswamy and Chitale (2012), Stahl et al. (2012) and Senge (2006). Another important area supporting knowledge transfer in an organization is relationships. This area has also been mentioned in research undertaken by Bozionelos (2006), Hezlett and Gibson (2007) and Singh et al. (2009). Based on other similar research (Carter \& Donohue, 2012; Shen \& Hall, 2009; van Dam, 2007), the authors have also suggested the necessity of working with coaches and mentors in order to work with knowledge and ensure its transfer. This area has not been utilized in most of the studied organizations. It is also necessary to educate and develop employees with regard to their work, social values and behavior each employee is an individual with a different perception and personality (Loke et al., 2012).
According to the survey, on-the-job methods such as coaching, shadowing, succession planning etc. are not commonly used. Surprisingly, the surveyed organizations also have partial problems with goals, aims and planning the process. The process goal is the crucial part of successful knowledge development and transfer according to Badura (1997), Judge, Thoresen, Bono and Patton (2001). There are still some blind spots to be filled and upgraded.

The process of knowledge transfer also takes time; this has been validated by many different pieces of research, i.e. Lord, Diefendorff, Schmidt and Hall (2010). The primary survey conducted in Czech organizations also found that the time investment strongly correlated to the employees' initiatives pertaining to knowledge development. Employees are bearers of knowledge, skills and abilities and their talent and willingness to provide these to an organization are key to the development and success of that organization (Claussen et al., 2014; Vivas-López, 2014). Similar approaches have also been stated by Stahl et al. (2012) and Al Ariss et al. (2014).

The acquisition, retention and development of knowledgeable, high quality employees is a priority for every organization (Nahapiet \& Ghoshal, 1998; Collings \& Mellahi, 2009; Ahsan et al., 2013).

The only thing that remains truly crucial in the effort to upgrade the organizations' level and economy is human capital and knowledge (McDonnell et al., 2014; Gururajan \& Fink, 2010; Manning, 2010). Therefore, organizations should focus on each individual and his or her knowledge management.

Employees who are being educated and developed are usually highly interested in working towards organizational goals and following the organizational strategy; they are communicative, cooperative, proactive, respectful, customer-friendly, willing and able to learn constantly (Li et al., 2009; Vnoučková, 2013). As Mazouch and Fischer (2011) and Gururajan and Fink (2010) have stated, measuring the level of education in organizations is necessary for predicting future development.

Bureš and Hájek (2007) stated that the significance of innovation is increasing for the national economy, which was also confirmed by the managers of significant corporations in 
the Czech Republic (for example, Microsoft, IBM and so on). The 21st century represents a stage which has been marked by a radical increase in innovations, changes and shifts from information to knowledge and from knowledge to wisdom.

Knowledge has been and increasingly will be the basic building block for every organization and national economy as a whole. With regard to the emphasis on the creation of a competitive advantage using a resource approach, organizations can use an entire range of tools for both acquiring and deepening knowledge and the organization's knowledge base. The organizations in the national economy can make use of the option of research and experimental development, the acquisition of intangible techniques and know-how, industrial design, training (the development of employees) or software development, etc.

Based on research by Levy (2011), the most problematic thing is not currently the creation or acquisition of knowledge, but the preservation of knowledge and its transfer to those who need it. The transfer of explicit knowledge is easier (Bocquillon et al. 2015; Massingham, 2015), but the most valuable knowledge is the tacit knowledge which the workers have in their heads. This knowledge is the most valuable for organizations and for the entire economy: intellectual property creates valuable goods and services which bring positive effects for individuals, organizations and the economy as a whole.

The correlations found in the presented article show the main ways which are utilized by employees and organizations to use and transfer their knowledge and potential. These results can be taken into account in a further analysis of knowledge transfer and the willingness of employees to transfer their knowledge based on organizational support.

There are also several other promising avenues of further research as well as this study. The impact of organizational relationships on knowledge transfer should be studied more deeply. Another interesting area is the analysis of the intrapersonal perception of knowledge transfer. This is another important and rarely studied area.

\section{Conclusion}

This paper has analyzed possible approaches to employee knowledge development in organizations nowadays. The results of the research have identified individual attributes and practices in organizational learning. This paper and its results describe the main ways which are used by organizations in order to grow constantly and to utilize their potential talents and leaders.

The main areas which affect knowledge development in organizations are based on cooperation and communication. This refers to both the organizational culture and the climate. Those areas are crucial for employee and organizational knowledge transfer and development. Another important area which supports knowledge transfer in an organization is relationships. It is suggested that organizations should work on and manage their knowledge in compliance with the organizational strategy. The surveyed organizations have partial problems with the goals, aims and process plans. However, set goals are a crucial part of successful knowledge development and transfer.

The analysis has also revealed the necessity of working with coaches and mentors in order to work with knowledge and its transfer. On-the-job methods such as coaching, shadowing, succession planning etc. are not commonly used. It is necessary to constantly educate and develop employees with regard to their work, social values and behavior.

The process of knowledge transfer also takes time; this has been validated in many pieces of research, i.e. Lord, Diefendorff, Schmidt and Hall (2010). A primary survey conducted in Czech organizations also found that the time invested strongly correlates to the employees' initiatives pertaining to knowledge development.

The following recommendations can be given based on the results of this paper: (1) identify and overcome the barriers to knowledge sharing through fostering effective relationships, (2) the employees' willingness to participate in the learning process needs to be enhanced, (3) the organization's management should introduce a reflective process and a career development process leading to effective knowledge sharing and (4) the role of the mentor and coach is crucial in efficient organizational learning. This paper has reviewed the approaches to employee and organizational learning practices in the Czech Republic. The results of the paper can be taken 
into account in further analyses and in the organization of adult education.

The paper's theoretical contribution lies in its general overview of the theoretical assumptions of knowledge transfer and support for the knowledge economy in organizations. On the other hand, the paper's practical contribution lies in the presentation of the results obtained from Czech organizations in the area of knowledge transfer and employee development, including recommendations for those organizations which plan to support knowledge transfer.

This contribution is a follow-up to the project of University - wide internal grant agency (CIGA), number 20141002 - Human resource branding using of the new strategic trends in organizations in the Czech Republic and is a follow-up to the project of University of Economics and Management.

\section{References}

Ahsan, N., Fie, D.Y.G., Foong, Y.P., \& Alam, S.S. (2013). Relationship between retention factors and affective organisational commitment among knowledge workers in Malaysia. Journal of Business Economics and Management, 14(5), 903-922. doi:10.3846/16111699.2012.701226.

Al Ariss, A., Cascio, W.F., \& Paauwe, J. (2014). Talent management: Current theories and future research directions. Journal of World Business, 49(2), 173-179. doi:10.1016/j. jwb.2013.11.001.

Allen, T.D., Eby, L.T., Poteet, M.L., Lentz, E., \& Lima, L. (2004). Career benefits associated with mentoring for protégés: a meta-analysis. Journal of Applied Psychology, 89(1), 127-136. doi:10.1037/0021-9010.89.1.127.

Arvanitis, S., Lokshin, B., Mohnen, P. et al. (2015). Impact of External Knowledge Acquisition Strategies on Innovation: A Comparative Study Based on Dutch and Swiss Panel Data. Review of Industrial Organization, 46(4), 359-382. doi:10.1007/ s11151-015-9450-7.

Bandura, A. (1997). Self-efficacy: The exercise of control. New York: Freeman.

Beech, N., \& Brockbank, A. (1999). Power/ knowledge and psychosocial dynamics in mentoring. Management Learning, 30(1), 7-25. doi:10.1177/1350507699301002.

Bozionelos, N. (2006). Mentoring and expressive network resources: their relationship with career success and emotional exhaustion among Hellenes employees involved in emotion work. The International Journal of Human Resource Management, 17(2), 362378. doi:10.1080/09585190500405009.

Bocquillon, R., Jouglet, A., \& Carlier, J. (2015). The data transfer problem in a system of systems. European Journal of Operational Research, 244(2), 392-403. doi:10.1016/j. ejor.2010.11.008.

Branham, L. (2009). 7 hidden reasons why employees leave. Prague: Grada Publishing.

Bureš, V., \& Hájek, L. (2007). Česká republika a znalostní ekonomika. Bratislava: VŠM.

Carter, V.A., \& Donohue, M. (2012). Whole Person Learning: Embedding Ethical Enterprise Leadership In Business Education. American Journal of Business Education, 5(6), 677-692. doi:10.19030/ajbe.v5i6.7390.

Claussen, J., Grohsjean, T., Luger, J., \& Probst, G. (2014). Talent management and career development: What it takes to get promoted. Journal of World Business, 49(2), 236-244. doi:10.1016/j.jwb.2013.11.007.

Collings, D.G., \& Mellahi, K. (2009). Strategic talent management: A review and research agenda. Human Resource Management Review, 19(4), 304-313. doi:10.1016/j.hrmr.2009.04.001.

Covey, S.R. (2011). 7 Habits of Highly Effective People. Prague: Management Press.

de Luis Carnicer, M.P., Martinez Sanchez, A., Perez, M., \& Maria Jose, V.J. (2004). Analysis of internal and external labour mobility: A model of job-related and non-related factors. Personnel Review, 33(2), 222-240. doi:10.1108/00483480410518068.

Dam, van N. (2007). 25 Best Practices in Learning \& Talent Development. USA: Lulu Publishers.

Disman, M. (2008). Jak se vyrábí sociologická znalost. Prague: Karolinum.

Fiol, C.M., \& Lyles, M.A. (1985). Organizational learning. Academy of Management Review, 10(4), 803-813.

Gannon, J.M., \& Maher, A. (2012). Developing tomorrow's talent: the case of an undergraduate mentoring programme. Education + Training, 54(6), 440-455. doi:10.1108/00400911211254244.

Gururajan, V., \& Fink, D. (2010). Attitudes towards knowledge transfer in an environment to perform. Journal of 
Knowledge Management, 14(6), 828-840. doi:10.1108/13673271011084880.

Hansen, T., Winther, L., \& Hansen, R.F. (2014). Human Capital in Low-Tech Manufacturing: The Geography of the Knowledge Economy in Denmark. European Planning Studies, 22(8), 1693-1710. doi:10.10 80/09654313.2013.797384.

Hezlett, S.A., \& Gibson, S.K. (2007). Linking mentoring and social capital: implications for career and organization development. Advances in Developing Human Resources, 9(3), 384412. doi:10.1177/1523422307304102.

Hobza, A. (2009). Evropská unie a hospodářské reformy. Praha: C.H. Beck.

$\mathrm{Hu}$, R. (2014). Migrant knowledge workers: An empirical study of global Sydney as a knowledge city. Expert Systems with Applications, 41(12), 5605-5613. doi:10.1016/j. eswa.2014.02.011.

Gupta, S., \& Polonsky, M. (2014). Interfirm learning and knowledge-sharing in multinational networks: An outsourced organization's perspective. Journal of Business Research, 67(4), 615-622. doi:10.1016/j. jbusres.2013.02.043.

Chidambaram, R. (2014). To become a knowledge economy. Current Science, 106(7), 936-941.

Judge, T.A., Thoresen, C.J., Bono, J.E., \& Patton, G.K. (2001). The job satisfaction-job performance relationship: A qualitative and quantitative review. Psychological Bulletin, 127, 376-407.

Kislingerová, E. (2011). Nová ekonomika: nové príležitosti? Praha: C.H.Beck.

Kloudová, K. et al. (2010). Kreativní ekonomika. Trendy, výzvy, přiležitost. Praha: Grada Publishing.

Kumaraswamy, K.S.N., \& Chitale, C.M. (2012). Collaborative knowledge sharing strategy to enhance organizational learning. Journal of Management Development, 31(3), 308-322. doi:10.1108/02621711211208934.

Kruss, G., McGrath, S., Petersen, I.H., \& Gastrow, M. (2015). Higher education and economic development: The importance of building technological capabilities. International Journal of Educational Development, 43, 2231. doi:10.1016/j.ijedudev.2015.04.011.

Li, J., Brake, G., Champion, A., Fuller, T., Gabel, S. \& Hatcher-Busch, L. (2009). Workplace learning: the roles of knowledge accessibility and management. Journal of Workplace Learning, 21(4), 347-364. doi:10.1108/13665620910954238.

Lilles, A., \& Rõigas, K. (2015). How higher education institutions contribute to the growth in regions of Europe? Studies in Higher Education, 21(14). doi:10.1080/03075079.2015.1034264.

Lisabonská smlouva. (2011). Smlouva pro Evropu 21. století. Retrieved June 12, 2015, from http://europa.eu/...index_cs.htm.

Loke, S.P., Downe, A.,G., Sambasivan, M., \& Khalid, K. (2012). A structural approach to integrating total quality management and knowledge management with supply chain learning. Journal of Business Economics and Management, 13(4), 776-800. doi:10.3846/161 11699.2011.620170.

Lord, R.G., Diefendorff, J.M., Schmidt, A.M., \& Hall, R.J. (2010). Self-regulation at work. Annual Review of Psychology, 61, 543-568. doi:10.1146/annurev.psych.093008.100314.

Manning, P. (2010). Explaining and developing social capital for knowledge management purposes. Journal of Knowledge Management, 14(1), 83-99. doi:10.1108/13673271011015589.

Massingham, P. (2015). Knowledge Sharing: What Works and What Doesn't Work: A Critical Systems Thinking Perspective. Systemic Practice and Action Research, 28(3), 197-228. doi:10.1007/s11213-014-9330-3.

Matula, J. (2011). Vztah pojmů znalostní ekonomika a znalostní společnost $k$ pojmům informační ekonomika a informační společnost. Retrieved June 14, 2011, from http://www. portalci.cz/ci-v-praxi/odborne-clanky/autorskeclanky/matula-j-vztah-pojmu-znalostniekonomika-a-znalostni-spolecnost-k-pojmuminformacni-ekonomika-a-informacnispolecnost.

Mazouch, P., \& Fischer, J. (2011). Adult Education Survey as Useful Additional Data Source for Human Capital Analyses and Prognoses. In Proceedings of the 8th International Conference on Efficiency and Responsibility in Education (ERIE 2011) (pp. 215-220). Prague.

McDonnell, A., Lavelle, J., \& Gunnigle, P. (2014). Human Resource Management in Multinational Enterprises: Evidence From a Late Industrializing Economy. Management International Review, 54(3), 361-380. doi:10.1007/s11575-014-0202-y.

Nahapiet, J., \& Ghoshal, S. (1998). Social capital, intellectual capital, and the 
organisational advantage. Academy of Management Review, 23(2), 242-266.

Nečadová, M., Soukup, J., \& Breňová, L. (2007). Teorie a praxe nové ekonomiky v ČR - konkurenceschopnost ČR v mezinárodním srovnání. Ekonomika a Management, 1(1).

Pearce, J.L., \& Randel, A.E. (2004). Expectations of organisational mobility, workplace social inclusion, and employee job performance. Journal of Organisational Behaviour, 25(1), 81-98. doi: 10.1002/job.232.

Peters, T. (2011). Small large things. Prague: Management Press.

Senge, P.M. (2006). The Fifth Discipline: The Art \& Practice of The Learning Organization. New York: Random Hause.

Shen, Y., \& Hall, D.T. (2009). When expatriates explore other options: Retaining talent through greater job embeddedness and repatriation adjustment. Human Resource Management, 48(5), 793-816. doi:10.1002/ hrm.20314.

Singh, R., Ragins, B.R., \& Tharenou, P. (2009). Who gets a mentor? A longitudinal assessment of the riding star hypothesis. Journal of Vocational Behavior, 74(1), 11-17. doi:10.1016/j.jvb.2008.09.009.

Stahl, G.K., Björkman, I., Farndale, E., Morris, S.S., Paauwe, J., Stiles, P., Trevor, J., \& Wright, P. (2012). Six principles of effective global talent management. MIT Sloan Management Review, 53(2), 25-42.
Svatoš, M. (2005). Globální trendy a znalostní ekonomika. Retrieved June 14, 2005, from http://www.agris.cz/Content/files/ main_files/70/148466/05svatos.pdf.

Tosici, N., \& Iordan-Constantinescu, N. (2014). Knowledge-based economy in the competitiveness equation. The case of the Republic of Serbia. Quality - Access to Success, 15(2), 220-226.

Vivas-López, S. (2014). Talent management and teamwork interaction: Evidence in large Spanish companies. International Journal of Business, 19(1), 30-43. doi:10.1108/01437721111158198.

Vnoučková, L. (2013). Employee Turnover and Retention. Prague: Adart.

Ing. Hana Urbancová, Ph.D. Czech University of Life Sciences Prague Faculty of Economics and Management Department of Management urbancova@pef.czu.cz

Ing. Lucie Vnoučková, Ph.D. University of Economics and Management Department of Management lucie.vnouckova@vsem.cz

doc. Ing. Šárka Laboutková, Ph.D. Technical University of Liberec Faculty of Economics Department of Economics sarka.laboutkova@tul.cz 


\section{Abstract}

\section{KNOWLEDGE TRANSFER IN A KNOWLEDGE-BASED ECONOMY Hana Urbancová, Lucie Vnoučková, Šárka Laboutková}

The knowledge economy currently presupposes that each organization manages its knowledge and in doing so intentionally endeavors to achieve a long-term competitive advantage. In other words the key source of success is no longer information as such, but the right knowledge which is associated with a specific bearer - employee who must constantly develop this in a currently highly competitive environment. The goal of this article is to identify and evaluate the conditions for the use of the resource approach focused on the management of knowledge in the current knowledge economy across all economic branches. The research is descriptive and empirical by nature, because the primary data has been collected using the survey method, including fact-finding techniques such as questionnaires and interviews. According to the results of the quantitative research focused on education in Czech organizations, $66.5 \%$ of the surveyed organizations make use of some type of education or training at work. However, one third of Czech organizations still do not educate their employees and do not work with knowledge development and management in any way. The following recommendations can be given to organizations nowadays: (1) identify and overcome the barriers to knowledge sharing through fostering effective relationships, (2) the employees' willingness to participate in the learning process needs to be enhanced, (3) the organization's management should introduce a reflective process and a career development process leading to effective knowledge sharing and (4) the role of the mentor and coach is crucial in efficient organizational learning. The main areas which affect knowledge development in organizations are based on cooperation and communication. This refers to both the organizational culture and the climate. Those areas are crucial for employee and organizational knowledge transfer and development.

Key Words: Knowledge transfer, knowledge-based economy, learning, organizations, survey.

JEL Classification: M12.

DOI: 10.15240/tul/001/2016-2-005 